\title{
PULMONARY LESIONS OF DISSEMINATED LUPUS ERYTHEMATOSUS
}

\author{
BY \\ S. I. RAPAPORT, L. MEISTER, F. M. STEELE, and S. R. CANIGLIA \\ From the Medical Service Veterans Administration Hospital, Long Beach, California
}

(RECEIVED FOR PUBLICATION SEPTEMBER 28, 1953)

Two patients were seen recently with distinctive pulmonary parenchymal lesions due to disseminated lupus erythematosus. The more classic manifestations such as skin lesions, carditis, polyserositis, and nephritis, were not at first apparent, but typical L.E. cells were demonstrated in the peripheral blood of both patients, and the diagnosis was confirmed by further study. This prompted us to review the published descriptions of the pulmonary manifestations of this disease and to observe in our patients the clinical effects of adrenocortical hormone therapy upon the lung lesions.

\section{Previous Descriptions of Lung Lesions}

Intercurrent pneumonia was described by Kaposi (1872) in his original account of the visceral lesions of lupus erythematosus. Many reports have since mentioned the frequency of pulmonary findings, particularly in the end stages of the disease. The serosal inflammation which results in acute fibrinous pleuritis, pleural effusion, and chronic fibrous pleuritis, has long been accepted as a distinctive feature, but the recognition of a specific pulmonary parenchymal lesion has been less certain, both at the bedside and at autopsy. Many accounts of visceral lesions fail to mention the lung parenchyma or to distinguish between a primary parenchymal lesion and a secondary infective pneumonia. Full consideration has not been given to the possibility that the frequent bouts of "broncho-pneumonia" suffered by these patients may be due to an underlying alteration of the respiratory membrane rather than to the debility of prolonged illness.

The concept of disseminated lupus erythematosus as a systematic alteration of the collagen ground substance was advanced by Klemperer, Pollack, and Baehr (1941), who referred to "long bouts of waxing and waning, migrating bronchopneumonia" characterizing the clinical course of their cases. At autopsy, they found that this pneumonia was "in no way specific", and the only lung lesion of systemic implication which they described was fibrinoid change in the small pulmonary arteries of a single case. This paucity of pulmonary parenchymal findings is the more striking in view of their detailed description of the lesions in the heart, kidney, spleen, lymph nodes, and serous membranes.
Rakov and Taylor (1942) appear to have been the first to focus particular attention upon the pulmonary $\vec{N}$ parenchyma in disseminated lupus. They described a $\rightarrow$ patient in whom pulmonary consolidation was the dominant finding from the onset of symptoms to death 8 months later. On gross examination both lower lobes 윽 were found to be atelectatic, although their bronchi were open. The microscopic picture was that of a chronic low-grade interstitial pneumonitis which had progressed to atelectasis. The authors called attention to a patient reported by Osler (1904) in his descriptions of the visceral manifestations of the erythema group of skin diseases, and to another described by Tremaine (1934 as subacute Pick's disease; both were probably instances of protracted primary pulmonary lesions in lupus erythematosus.

Foldes (1946) described the clinical and pathological findings in a patient with disseminated lupus erythematosus who died of respiratory failure due to massive atelectasizing pneumonitis.

Teilum (1946) delineated what he considered to be the specific morphological characteristics of the pulmonary lesion of lupus erythematosus. He stated that the histological characteristics of the lung lesion serve as prototypes of the various stages of tissue injury which occur in this disorder. He described a focal allergic pneumonia which varied in intensity in different parts of the lung but was most pronounced just beneath the pleura. He also recorded the presence of fibrinoid thread-and-bandlike masses in the interalveolar septa, areas of complete necrosis of the septal wall, accumulations of histiocytes, organization of areas of fibrinoid necrosis to form small granulomata, areas of fibrosis, and pronounced allergic vascular changes.

Baggenstoss (1952) stated that there is no pathognomonic pulmonary parenchymal lesion, but he and his colleagues have also observed the chronic interstitial atelectasizing pneumonitis described by Rakov and Taylor, and by Foldes. In addition, Baggenstoss described a "peculiar basophilic mucinous oedema of the alveolar walls and of the peribronchial and perivascular tissues"; he noted that these lesions are quite separate from the ordinary pyogenic and fibrinous types of bronchopneumonia which may complicate the disease.

That this differentiation may be difficult clinically can 
be inferred from a review by Tumulty and Harvey (1949). Abnormal pulmonary findings had been recorded at some time during the illness of nineteen of 32 patients autopsied at the Johns Hopkins Hospital, but the lungs of only three showed "classical lesions of this disease", and these were patients with minimal clinical evidence of pulmonary involvement. In one, physical examination of the chest was negative, but $x$ rays revealed a diffuse nontuberculous type of infiltration similar to that found in our own second case. This infiltration, on histological examination, was found to consist of "focal haemorrhages and focal alveolar exudate with organization, thought to be typical of the changes seen in rheumatic fever, periarteritis nodosa, and sulphonamide hypersensitivity".

Sante and Wyatt (1951), in a discussion of the radiological characteristics of antigenic pneumonitis, stated that there was "little, if any, indication of lung involvement" in lupus erythematosus until just before the final stages of the disease. However, Thorell (1952) described in detail what he considered to be characteristic chest-film findings in disseminated lupus erythematosus. Small, often bilateral pleural effusion and irregular pleural thickening were most common, and these were frequently accompanied by parenchymal changes consisting of mottled and streaky consolidation, mostly subpleural in location and usually confined to the bases. Thorell suggested that this combination of pleural and parenchymal changes should warn the radiologist of the diagnostic possibility of disseminated lupus. In his series there were no films of pulmonary parenchymal changes without accompanying pleural changes, massive pulmonary consolidation, or atelectasis.

Thus it is apparent that while pulmonary lesions in disseminated lupus are frequent, they are often atypical and difficult to evaluate. It may be that the lungs are as common a site of primary involvement as the heart, kidneys, or serous membranes. This is not definitely known because of the tendency in the past for clinicians to label parenchymal lesions as "pneumonia" without further qualification, and because the histological lesion is still in the process of identification by the pathologist. Primary involvement may occur as asymptomatic, diffuse infiltrates discoverable only by $x$-ray examination, or, on the contrary, it may present as a massive pulmonary consolidation or atelectasis. Perhaps the most common pattern is that of patchy, shifting areas of pneumonitis, usually at the bases and associated with a pleural reaction. It would seem important to recognize such lesions clinically, since their significance and treatment are so different from that of a secondary bronchopneumonia. The two cases described below illustrate some features of their clinical behaviour.

\section{Case Reports}

Case 1, a white marine engineer, aged 44, was referred to this hospital from a public health clinic in October,
1952, with a diagnosis of probable primary atypical pneumonia.

History.- - He stated that he had been ill since February, 1952, when he developed "the shingles". This was soon followed by weakness, generalized muscle aching, numbness, and tingling of hands and feet in the morning, coughing, shortness of breath, and a pleurisy-like pain, which spread across his lower anterior chest and into his left shoulder. He became febrile, failed to respond to intramuscular injections of penicillin, and, in late April, 1952, he entered a hospital. His temperature on admission was $103 \cdot 5^{\circ} \mathrm{F}$. He was short of breath and had a cough productive of frothy, mucoid sputum, a bilateral pleurisy, and bilateral crepitant basilar rales. A chest film (Fig. 1) revealed "bilateral bronchopneumonia" with evidence of pleural exudate. An electrocardiogram disclosed "marked ST segment shift suggestive of the acute stage of pericarditis". One examiner's note mentioned a "low white count". The patient continued febrile and severely ill despite the administration of penicillin, aureomycin, terramycin, and chloromycetin. He lost $60 \mathrm{lb}$. in weight within 6 weeks. Sputum examination for bacteria, fungi, malignant cells, and eosinophils, test for cold agglutinins, and a coccidiodin skin test were all negative. Blood cultures, febrile agglutinins and a heterophil agglutination test were negative. A bone marrow examination with a search for L.E. cells was reported as negative, but the type of preparation made was not stated.

Although a diagnosis was not established, ACTH therapy was initiated about June 1 , and he received four injections daily of an unknown amount for 25 days. He became afebrile, gained $20 \mathrm{lb}$. and noted marked relief of his chest pain. A progress chest film (Fig. 2) disclosed "partial resolution of the bilateral pneumonitis". He was then sent home on one daily injection of ACTH, but within 3 weeks the fever and other symptoms returned, and in mid-July he was admitted to another hospital. His pulse and respirations were rapid on admission, but physical examination of his lungs was reported as negative. A chest $x$ ray showed what was interpreted as a low grade pneumonitis at the left base with a suggestion of a low grade pleural reaction. A white blood cell count was 5,600 per cu. $\mathrm{mm}$. One of several urine analyses revealed 10-20 red blood cells per high-powered field. An unknown amount of ACTH was then given until the end of July, and the patient was discharged from the hospital at the end of August with a diagnosis of primary atypical pneumonia. A chest film prior to discharge (Fig. 3) was essentially unchanged from the admission film. During the next 6 weeks he was followed as an out-patient, but when his original symptoms of pleurisy, breathlessness, weakness, and numbness and tingling of the extremities again became worse, he was referred to this hospital for further study.

Examination.-The patient was an alert, well-developed, middle-aged, white man (height $6 \mathrm{ft} .2$ in., weight $180 \mathrm{lb}$.). Temperature $99 \cdot 5^{\circ}$ F.; pulse 90 and regular; blood pressure, 94/70. Respiration rapid and restricted by sharp, lower left anterior chest pain radiating into the left shoulder on attempted deep inspiration. Head and neck normal. Tactile fremitus and percussion resonance impaired over both lung bases. Bilateral, crepitant, late inspiratory rales, persisting after cough, heard at both bases. PMI felt in fifth intercostal space at anterior axillary line. Heart sounds quiet, with a soft basal systolic murmur. Abdominal and neurological findings within normal limits. Slight periarticular swelling and tenderness of right fourth metacarpophalangeal joint 
were noted. Skin clear except for seborrhoeic macular rash over "V" area of chest.

\section{Laboratory Data:}

Haemoglobin, 14.4 g.; white blood cell count, 4,350; differential count, 74 per cent. neutrophils, 21 per cent. lymphocytes, 3 per cent. monocytes, 1 per cent. eosinophils, 1 per cent. basophils.

Sedimentation Rate: $33 \mathrm{~mm}$./hr (Wintrobe uncorrected).

Urine analysis: specific gravity, 1.014-1.020; albumin, negative to a trace; sugar, negative; sediment, occasional to many white blood cells, no red blood cells, negative tests for occult blood.

Cardiolipin and Kahn tests: negative.

Blood chemistry: blood urea nitrogen, $13 \mathrm{mg}$. per cent.; cephalin-cholesterol flocculation, 1+; thymol turbidity, 3 units; total serum proteins, $6 \cdot 6 \mathrm{~g}$. per cent.; albumin, $3.6 \mathrm{~g}$. per cent.; globulin, $3.0 \mathrm{~g}$. per cent. Electrophoretic analysis of serum proteins: elevation of $\alpha 2$ and $\gamma$ globulins.

Radiology.-Chest film on admission disclosed prominent left ventricular border, considerable mottling throughout right lung field, particularly at base, and some mottling at left base. This appearance suggested a resolving bilateral pneumonitis.

Electrocardiogram.-Within normal limits.

Biopsy.-Kveim test and random muscle biopsy for evidence of sarcoid (Myers and others, 1952) both negative.

L.E. Cell Preparation (made by defibrination of the patient's peripheral blood immediately following withdrawal and preparation of smears of the buffy coat after 2 hrs' incubation at room temperature) revealed large masses of L.E. rosettes and many typical L.E. cells.

Therapy.-The patient was confined to bed with his head elevated for comfort. Rapid, shallow breathing persisted, as did his complaints of pleuritic pain and numbness and tingling of his hands and feet. Walking to the bathroom left him breathless. He did not cough, and auscultation of the lungs revealed only a few crepitant rales at the bases. There was evening fever to about $100^{\circ}$ F. After 3 weeks' symptomatic therapy he was unimproved. Therefore, in view of the positive L.E. cell test, ACTH therapy was started. He received 10 i.u. ACTH (Armour) daily by intravenous drip in $1,000 \mathrm{ml}$. 5 per cent. dextrose in water, given over 16 to 18 hours (Mandel and others, 1951). Within 24 hours he felt better and his temperature returned to normal. During the first week of therapy his numbness and tingling vanished, and he was able to breathe deeply with only a twinge of pleural pain. Within 2 weeks his sedimentation rate was normal. On the 17 th day of treatment the dosage of ACTH was reduced to $5 \mathrm{mg}$. daily because a pronounced Cushing effect had been obtained. A chest film at this time revealed considerable clearing of the pulmonary infiltrations. A defibrinated blood smear made on the 21st day of therapy revealed only an occasional questionable L.E. cell, and a repeat smear a few days later was completely negative. On the 67th day of ACTH therapy the patient felt completely well except for a rare stab of pleural pain; his chest film was clear except for vague, minimal, residual mottling at the bases; and all other laboratory tests, including electrophoretic analysis of serum proteins, were within normal limits.

ACTH was gradually discontinued for one week. During this the patient developed a swollen, tender right lower leg believed to be due to a deep thrombophlebitis. He was placed on dicumarol and kept in bed for about 6 weeks until the tenderness and swelling in the leg subsided enough to permit ambulation.

Results.-A full 2 months after ACTH was stopped, his status was re-evaluated. He stated that he felt well. He had no chest pain or shortness of breath. Physical examination was negative if he wore an elastic stocking when ambulant to prevent swelling of his right ankle. A chest film (Fig. 4) showed only slight accentuation of the bronchovascular markings in the first and second interspaces on the right and possibly in the bases. Urine analysis, blood count and serum protein determination were within normal limits. Another L.E. cell test was negative. The only abnormality discovered was a persistently elevated sedimentation rate $(40,39$, and $33 \mathrm{~mm}$./ $\mathrm{hr}$ on three determinations.)

He was therefore discharged to the care of another clinic.

Comment.-This case clearly illustrates that for many months disseminated lupus erythematosus may manifest itself primarily as pulmonary disease. From the onset and throughout the long course of the illness, a bilateral, shifting pneumonitis with pleuritis was the outstanding clinical finding, and drew attention from the signs of other organ involvement. The result was a thorough search for primary pulmonary disease. During the first hospitalization, many sputum cultures for bacteria and fungi, sputum examinations for malignant cells and for eosinophils, tests for cold agglutinins, and a coccidioidin skin test were done. Primary atypical pneumonia, $\mathbf{Q}$ fevero psittacosis, and other viral pneumonitides were thought of because of the low white count and the failure to respon to antibiotic therapy. During the second hospitalization studies were repeated to exclude tuberculosis, and the illness was finally considered to be primary atypical pneumonia. In our hospital the diagnoses of sarcoid and of lymphomatous pulmonary infiltrations were at first seriously considered.

In retrospect, certain clues stand out which point to the correct diagnosis:

(i) numbness and tingling of hands and feet;

(ii) electrocardiographic evidence of acute pericarditis found during the first hospitalization, and the cardiac enlargement visible on the chest films;

(iii) red cells in one urine specimen during the second hospitalization;

(iv) borderline elevation of serum globulin discovered during the third hospitalization.

The diagnosis of disseminated lupus erythematosus was suspected late in the course of the first hospitalization but was apparently discarded when L.E. cells were not found in a bone-marrow preparation. We can only speculate as to why the cells were not seen, since later they were easily demonstrated. The patient had been on ACTH therapy for 12 days before the first test was done, but this seems insufficient treatment to have suppressed the phenomenon completely. A better reason is the lack of sensitivity of the bone-marrow technique. Although the details of the procedure used in this instance are unknown, most bone-marrow preparations are made from heparinized marrow after 20 to $30 \mathrm{~min}$. incubation. 

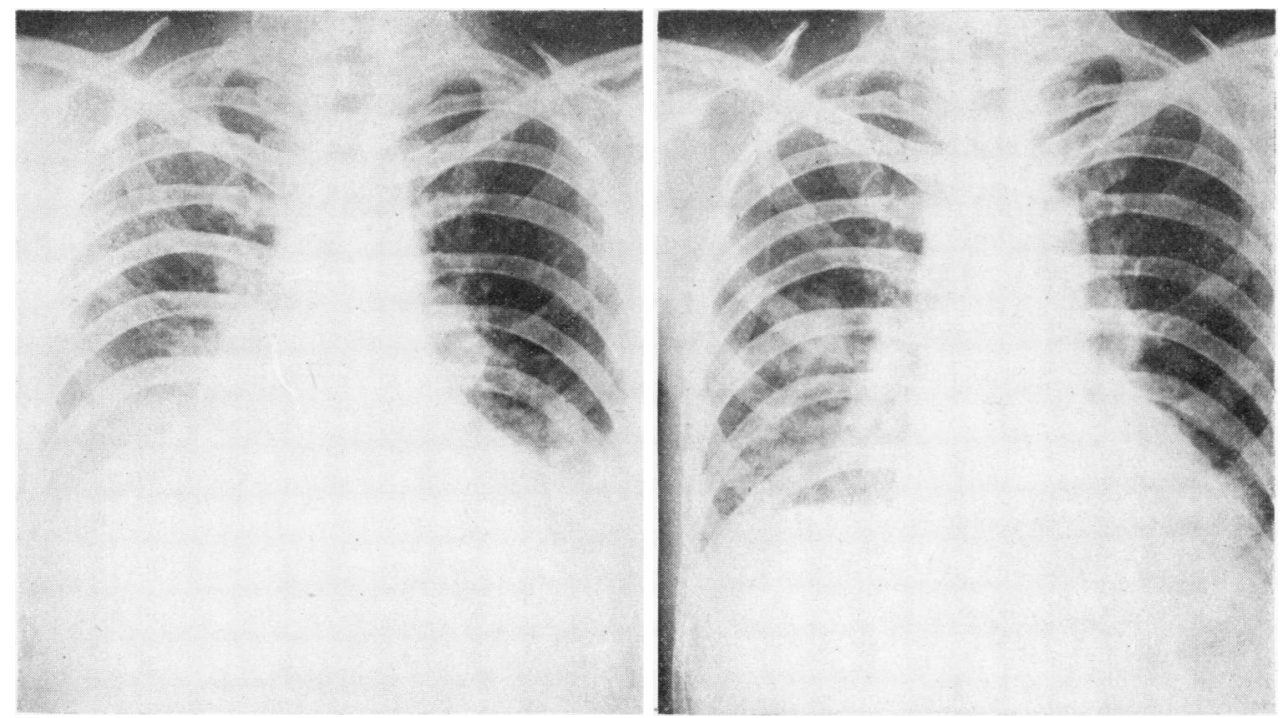

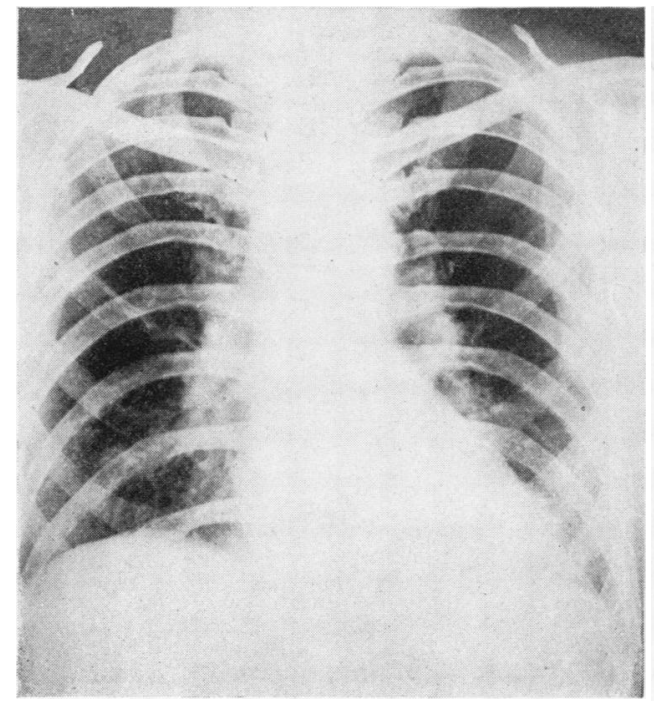

Fig. 1.-Case 1, May 3, 1952.

Fig. 3.-Case 1, August 18, 1952.

Zimmer and Hargraves (1952) have shown that a peripheral blood method which permits coagulation to occur, and which provides for a $2-\mathrm{hr}$ incubation period is much more sensitive than the older bone-marrow method. The defibrinated blood technique, which we used to find the L.E. cells, meets these requirements and is one of the most sensitive techniques now available.

The experiences with the L.E. cells tests in this case illustrate two points:

(i) when a laboratory test is considered pathognomonic of a disease, a false negative result will usually cause that diagnosis to be discarded despite good evidence in its favour.

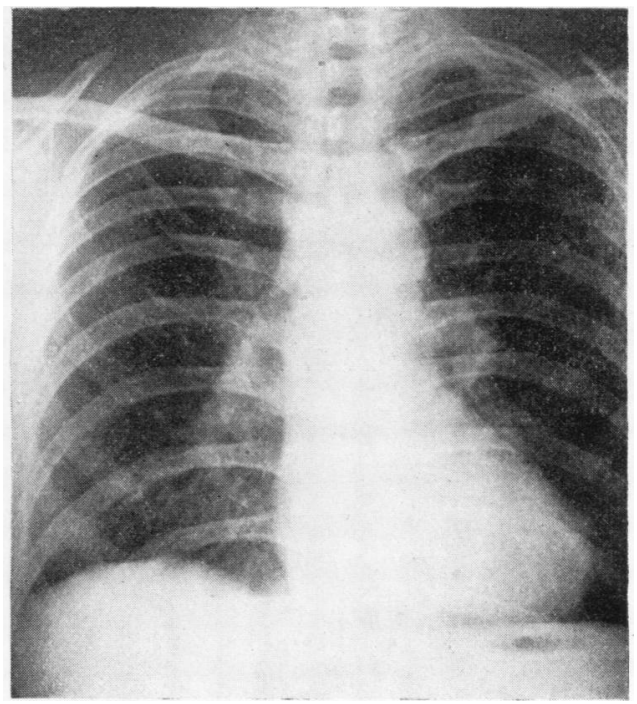

Fig. 2.-Case 1, June 19, 1952.

Fig. 4.-Case 1, March 30, 1953.

(ii) when we saw the patient a diagnosis of disseminated lupus could not have been made without a positive L.E. cell test. He had no significant skin lesions, his arthritis was minimal, his pericarditis had subsided, and his urinary sediment was not typical of the disease. The basis for his fever, pulmonary infiltrations, and abnormal serum protein electrophoretic pattern would have remained obscure without the demonstration of the L.E. cells. Perhaps L.E. cells should be searched for more often in patients with similar atypical, persistent pulmonary infiltrations.

The pulmonary lesions in this patient were clinically characterized initially by cough productive of some 
mucoid sputum, dyspnoea, and pleural pain. The sputum was never profuse nor purulent. The cough soon became non-productive and disappeared, but the pleurisy and dyspnoea persisted. When the patient was first seen by us, 7 months after the onset of symptoms, the cough was gone, and the severe dyspnoea seemed out of proportion to the findings, though it could be explained in part by the pleural pain. The persistence of pleuritis and the absence of purulent sputum at any time probably reflect an interstitial and largely sub-pleural location of the pneumonitis, and aid in its differentiation from a secondary infective bronchopneumonia.

Figs 1-4 illustrate many of the characteristics described by Thorell (1952), particularly the association of a pleural reaction with mottled and streaky consolidations most prominent in the bases. The shifting nature of the infiltrations is best seen by a comparison of Figs 2 and 3; a large patch of pneumonitis in the right mid-lung field disappeared, but increased density appeared in the left base. Fig. 4, taken 2 months after ACTH therapy was stopped, reveals the clearing which followed prolonged adrenocortical hormone therapy. Subjective improvement, fall of temperature and sedimentation rate to within normal limits, and even disappearance of the L.E. cell phenomenon, preceded maximum clearing of the pulmonary infiltrations radiologically. This shows that ACTH therapy should be prolonged well after the usual signs of disease activity have subsided.

Case 2, a 35-year-old coloured janitor, was admitted to the hospital in October, 1952, because of painful swelling of the fingers, wrists, and toes of 3 wks' duration.

History.-For $2 \mathrm{mths}$ he had noticed increasing weakness, and during this period had lost about $20 \mathrm{lb}$. He had also received some pills thought to be sulpha-drug tablets and some injections for "infected urine". For 2 yrs he had experienced intermittent anorexia. A systemic review was negative except for a long history of hay-fever. There were no other respiratory symptoms.

Examination.-The patient was thin, and appeared chronically ill, but was afebrile. Head negative. Small, rubbery, non-tender lymph nodes in both posterior triangles of neck.

Cardiovascular system normal except for a questionable Grade 1 apical systolic murmur.

Respiratory rate and excursion normal. Percussion note resonant throughout, but medium, persistent crepitant rales heard over both lower lung fields.

Abdominal and neurological examinations negative.

Enlarged, firm, non-tender lymph nodes also felt in axillae, and in epitrochlear and inguinal areas.

Prominent superficial varicosities of right leg.

Increased warmth and symmetrical fusiform swelling of proximal interphalangeal joints of both hands, wrists, and metatarsophalangeal joints.

\section{Laboratory Data:}

Haemoglobin, $15 \cdot 2 \mathrm{~g}$.; white blood cell counts, 3,300 to 5,800 ; initial differential count, 41 per cent. neutrophils, 58 per cent. lymphocytes, and 1 per cent. eosinophils. Later differential counts within normal limits.

Sedimentation Rate: 42, 20, and $42 \mathrm{~mm}$./hr (Wintrobe uncorrected).

Urine analyses: specific gravity 1.016-1.024; albumin negative; sugar negative; sediment, few to large numbers of white blood cells, no red blood cells or casts. 24-hour urine protein excretion: $300 \mathrm{mg}$.

Cardiolipin and Kahn tests: negative. Antistreptolysin titre: 100 Todd units. Differential sheep red cell agglutination test for rheumatoid arthritis: negative.

Blood chemistry: blood urea nitrogen $16 \mathrm{mg}$. per cent.; cephalin-cholesterol flocculation $1+$; thymol turbidity test 3 units; total protein $7.6 \mathrm{~g}$. per cent.; albumin $4 \cdot 3$ g. per cent.; globulin $3 \cdot 3$ g. per cent.

Radiology.-Admission chest film (Fig. 5) disclosed streaky and mottled infiltrations throughout both lower lung fields which were interpreted as bilateral pneumonitis.

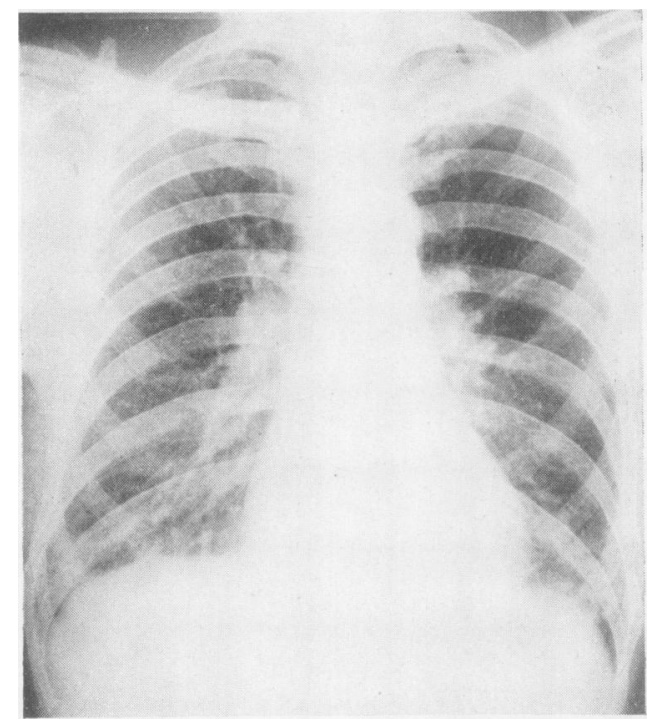

Fig. 5.-Case 2, October 8, 1952, several films taken up to May 9, 1953, are identical.

Skin.-Tuberculin skin test positive. Coccidioidin, histoplasmin, and Frei skin tests negative.

Cultures of three gastric washings grew no tubercle bacilli.

Electrocardiogram.-T wave inversions in leads III and AVF suggestive of posterior wall ischaemia.

Biopsy.-Cervical lymph node revealed only lymphoid hyperplasia; random muscle biopsy was negative.

L.E. Cell Preparation made from heparinized blood after $30 \mathrm{~min}$. incubation showed suspicious rosettes but no definite L.E. cells. Later test, using defibrinated blood incubated for $2 \mathrm{hrs}$, revealed many typical L.E. cells.

Progress.-At first the patient had intermittent fever to about $100-101^{\circ} \mathrm{F}$. The painful swelling of hands, wrists, and feet did not improve, and he developed migratory pain, tenderness, and stiffness of the shoulders, elbows, and knees. Despite the physical and röentgen findings of pulmonary involvement, no cough, sputum, dyspnoea or chest pain was ever noted.

Diagnosis.-When the first L.E. cell test, lymph node biopsy, and muscle biopsy were all reported as negative, a diagnosis of atypical rheumatoid arthritis with rheumatoid lung disease was seriously considered. 
Therapy.-About one month after admission ACTH therapy was started. For 4 days 10 i.u. daily were given in $1,000 \mathrm{ml}$. 5 per cent. dextrose in water, by intravenous drip over an 18-hour period. The dosage was then reduced to 5 i.u. daily.

Results.-Within 24 hours there was definite improvement in his joints. He became afebrile and noted a return of appetite and strength. Only minimal swelling of the fingers could be found after 4 days of treatment, and after 10 days, the palpable lymph nodes were much smaller. However, crepitant rales persisted at both lung bases, and a progress chest film showed no improvement. Because of this, and the establishment of the diagnosis of disseminated lupus erythematosus by the discovery of the L.E. cells on the second preparation, the dosage of ACTH was increased to 10 i.u. daily, maintaining the 18-hour duration. This was continued for 2 weeks until a pronounced Cushing effect with mild diastolic hypertension was obtained, and it was felt that the dosage could be lowered to 5 i.u. again. ACTH therapy was continued for a total of almost 10 weeks, with maintenance of the Cushing effect throughout the remainder of this period. The patient felt completely well and was impatient to leave the hospital, but there was no improvement in his pulmonary findings, and his sedimentation rate was not always within the normal range, and the $T$ wave inversions in leads III and AVF persisted. Despite these findings, ACTH therapy was discontinued to determine whether or not cortisone maintenance therapy would be required to prevent progressive and disabling disease activity. He was given leave for a short period on no therapy. When recalled, 7 weeks after the end of treatment, he stated that he felt well. There was no evidence of joint disease. Slight lymphadenopathy was found. Rales were still heard at the lung bases, and a chest film was identical with the first film taken 6 months earlier. A white blood cell count was 4,000 with a normal differential. Urine analysis was normal.

He was permitted to return to his work as a janitor, but within a few weeks a relapse became gradually apparent, and he was therefore re-admitted. He again responded promptly to ACTH therapy, but $x$-ray examination showed that the pulmonary infiltrates remained unaltered. It is now thought that continuous maintenance therapy will be required, particularly if the patient is to find employment.

Follow-up.-This patient was seen on November 12, 1953; he seemed well and had no complaints, but râles were still present at both bases posteriorly. He had had no therapy for 2 months. It was evident that the remission was precarious and incomplete.

Comment.-On purely clinical grounds, it was impossible to distinguish the manifestations of disseminated lupus erythematosus (without lupus) in this Negro from either polyarthritis attributable to sarcoidosis, of which ten cases are described in the world literature (Myers and others, 1952), or from rheumatoid arthritis with pulmonary lesions, of which but five published cases have been directly reported (Ellman and Ball, 1948; Bloom and Rubin, 1950; Leys and Swift, 1949). One difference from sarcoidosis appeared in retrospect, i.e. the absence of hilar lymphadenopathy in our patient as contrasted with its presence in each of the four cases of sarcoidosis with polyarthritis reported by Myers and others. However, that diagnosis was excluded by the negative lymph node and muscle biopsies.
The joint manifestations of lupus erythematosus and rheumatoid arthritis may be indistinguishable, even to the $x$-ray finding of a destructive joint process in the former (Tumulty and Harvey, 1949). As in this patient, the haemagglutination test for rheumatoid arthritis as modified by Heller and others (1949) may not be applicable in the absence of $x$-ray evidence of joint damage. Synovial punch biopsy would seem of limited value in the differentiation of the two conditions. Therefore, when polyarthritis suggestive of rheumatoid arthritis is associated with pulmonary lesions, it would seem important to look carefully for L.E. cells. They may furnish, as in this instance, the only direct approach to the correct diagnosis.

The complete absence of respiratory symptoms over many months despite the extensive, unchanging infiltrations seen on the chest films is further evidence of an interstitial location of the pulmonary lesion. The failure to find significant pleural involvement over many months indicates that the combination of a parenchymal and pleural lesion is not a prerequisite to the diagnosis of pulmonary lupus erythematosus. However, it is likely that evidence of pleuritis will be found at some time in most cases. Unlike Case 1, the pulmonary lesions in Case 2 remained unchanged during a course of ACTH therapy which was adequate to produce striking clinical remission of more symptomatic facets of the disease as well as Cushing's syndrome.

\section{Summary}

The published descriptions of pulmonary parenchymal lesions in disseminated lupus erythematosus are reviewed, and two cases are reported which illustrate the clinical manifestations of such lung lesions. An awareness of their frequency and atypical behaviour is necessary for two reasons:

(i) to recognize cases in which pulmonary infiltrates are the major symptom of disease,

(ii) to differentiate, in established cases, primary parenchymal disease from a secondary infective pneumonia.

In the first patient here reported, a bilateral, shifting pneumonitis with pleuritis so overshadowed evidence of other organic involvement that an extensive search was made for primary pulmonary disease. In the second patient, the combination of bilateral pulmonary infiltrates, peripheral lymphadenopathy, and polyarthritis closely mimicked sarcoidosis with polyarthritis, and rheumatoid lung disease. A correct diagnosis was established only after the demonstration of typical L.E. cells.

Dyspnoea and pleural pain were the respiratory complaints of one patient. The other patient was asymptomatic. The absence of cough and purulent sputum is evidence of an interstitial location of the pulmonary lesion.

The $x$-ray findings in the first case consisted of 
shifting, patchy, mottled densities, most pronounced in the bases, and associated with a pleural reaction. In the second case, there were extensive, streaky, mottled infiltrates throughout both lower lung fields without evidence of pleuritis.

The response of the pulmonary lesions to ACTH therapy varied; in one patient there was complete clearing, and in the other the pulmonary lesions remained unchanged, despite ACTH therapy sufficient to induce a pronounced Cushing effect.

\section{REFERENCES}

Baggenstoss, A. H. (1952). Proc. Mayo Clin., 27, 412.

Bloom, J., and Rubin, J. H. (1950). Canad. med. Ass. J., 63, 355.

Ellman, P., and Ball, R. E. (1948). Brit. med. J., 2, 816.

Foldes, J. (1946). Amer. J. clin. Path., 16, 160.

Heller, G., Jacobson, A. S., and Kolodny, M. H. (1949). Proc. Soc. exp. Biol., N.Y., 72, 316.

Israel, H. L. (1953). Amer. J. Med. Sci., 226, 387.

Kaposi, M. K. (1872). Arch. Derm. Syph., Wien, 4, 36

Klemperer, P., Pollack, A. D., and Baehr, G. (1941). Arch. Path. 32, 569 .

Leys, D. G., and Swift, P. N. (1949). Brit. med. J., 1, 434.

Mandel, W., Singer, M. J., Gudmundson, H. R., Meister, L., and Modern, F. W. S. (1951). J. Amer. med. Ass., 146, 546.

Myers, G. B., Gottlieb, A. M., Mattman, P. E., Eckley, G. M., and Chason, J. L. (1952). Amer. J. Med., 12, 161.

Osler, W. (1904). Amer. J. med. Sci. 127, 1 .

Rakov, H. L., and Taylor, J. S. (1942). Arch. intern. Med., 70, 88.

Sante, L. R., and Wyatt, J. P. (1951). Amer. J. Roentgenol., 66, 527.

Teilum, G. (1946). Acta med. scand., 123, 126.

Thorell, I. (1952). Acta radiol., Stockh., 37, 8.

Tremaine, M. J. (1934). New Engl. J. Med., 211, 754.

Tumulty, P. A., and Harvey, A. M. (1949). Bull. Johns Hopk. Hosp. $85,47$.

Zimmer, F. E., and Hargraves, M. M. (1952). Proc. Mayo Clin., $27,424$.

\section{Lésions pulmonaires du lupus érythémateux disséminé RÉSUMÉ}

On passe en revue les descriptions publiées des lésions pulmonaires parenchymateuses dans le lupus érythémateux disséminé et on relate à titre d'exemple deux cas de telles manifestations pulmonaires cliniques. La connaissance de leur fréquence et de leur comportement atypique est nécessaire pour deux raisons:

(i) pour reconna tre les cas dans lesquels les infiltrats pulmonaires constituent le symptôme majeur de la maladie;

(ii) pour différencier, à la période d'état, entre la maladie parenchymateuse primaire et la pneumonie infectieuse secondaire.

Dans le premier cas une pneumonite bilatérale migratrice avec pleurite éclipsait les signes de l'atteinte des autres organes à un tel point qu'on a fait des recherches approfondies pour trouver la maladie pulmonaire primaire. Dans le deuxième l'ensemble des infiltrats pulmonaires bilatéraux, de la lymphadénopathie périphérique, et de la polyarthrite simulait une sarcoïdose accompagnée d'une polyarthrite et de la maladie pulmonaire rhumatismale. On ne fit le diagnostic correct qu'après avoir trouvé les cellules typiques du lupus érythémateux.

Du coté respiratoire, l'un des malades se plaignait de dyspnée et de douleur pleurale, l'autre ne présentait aucun symptôme. L'absence de la toux et de l'expectoration purulente indique qu'il s'agissait d'une localisation intersticielle de la lésion pulmonaire.

Radiologiquement, il y avait chez le premier malade des condensations mobiles, inégales et tachetées, plus prononcées aux bases et associées à une réaction pleurale. Chez le deuxième il y avait des infiltrats étendus, striés et tachetés aux deux bases pulmonaires sans signes de pleurite.

$\mathrm{La}$ réponse des lésions pulmonaires au traitement par l'ACTH était variable. Chez un malade on a observé la guérison complète; chez l'autre les lésions pulmonaires ont demeuré, malgré le traitement par l'ACTH suffisant à provoquer un effet de Cushing prononcé.

Lesiones pulmonares del lupus eritematoso diseminado SUMARIO

Se revisan las descripciones publicadas de las lesiones pulmonares parenquimatosas en el lupus eritematoso diseminado y se relatan dos casos ilustrativos de tales manifestaciones pulmonares en clínica. El conocimiento de su frecuencia y de su comportamiento atípico es necesario por dos razones:

(i) para reconocer los casos en que los infiltrados pulmonares constituyen el síntoma mayor de la enfermedad;

(ii) para diferenciar, en casos establecidos, entre la enfermedad parenquimatosa primaria y la neumonia infecciosa secundaria.

En el primer caso una neumonitis bilateral móvil cone pleuritis eclipsó las manifestaciones en otros órganos dę manera que se hicieron investigaciones extensas en buscade la enfermedad pulmonar primaria. En el segundo ef conjunto de infiltrados pulmonares bilaterales, de linfadenopatia periférica y de poliartritis hizo pensar a una sarcoidosis con poliartritis y con enfermedad reumatoide del pulmón. Tan sólo el hallazgo de las células típicas del lupus eritematoso llevó al diagnóstico correcto.

Del lado respiratorio, un enfermo se quejó de dispnea y de dolor pleural, el otro no tuvo síntoma alguno. La ausencia de la tos y de la expectoración purulente indica una localización intersticial de la lesión pulmonar.

Radiológicamente, en el primer enfermo hubo sombras móviles, moteadas y abigarradas, más pronunciadas en las bases y asociadas con una reacción pleural. En el segundo hubo infiltrados extensos, rayados y moteados en la parte inferior de ambos pulmones sin manifestaciones de pleuritis.

La respuesta de las lesiones pulmonares al tratamiento con ACTH fué variable. El primer enfermo curó completamente; en el segundo las lesiones pulmonares permanecieron a pesar del tratamiento con ACTH, suficiente para producir un efecto pronunciado de Cushing. 